\title{
Free Movement of Capital and Economic and Monetary Union in the $\mathrm{EU}$
}

\author{
Armin Cuyvers
}

\subsection{Introduction}

Full economic integration requires both free movement of capital and Economic and Monetary Union (EMU). ${ }^{1}$ Free movement of capital, moreover, is a prerequisite for EMU. Considering their close connection, this Chapter covers both free movement of capital and EMU in the EU. In line with the overall objective of this book, the emphasis of the analysis will be on the early days and the gradual development of the free movement of capital and EMU. In addition, this Chapter briefly analyses the devastating euro crisis that has been plaguing the EU since 2008. Considering its ambition to create a single currency, understanding this crisis and its causes is important to the EAC for two reasons. Firstly, the crisis uncovered several structural flaws in the way EMU has been set up in the EU. Secondly, the EAC may learn from the different measures adopted so far to address these structural flaws, even if real structural solutions have not been found yet. Even if the economic and political contexts differ in significant ways, the insights provided by the EU experience may hopefully help the EAC to avoid the staggering financial and political costs the EU has paid so far. In terms of money, the bill already exceeds two trillion euro (€2.000.000.000.000), not even counting lost growth and secondary effects, whereas the full political costs, perhaps including Brexit, are not even fully clear yet. Introducing an EMU, therefore, is a high stakes game, with real benefits, but also very real risks.

\subsection{Free Movement of Capital}

For a long time, the free movement of capital was the ugly duckling of the four freedoms. Whereas its siblings emerged from the 1957 Treaty of Rome as

1 C. Barnard, The Substantive Law of the EU: The Four Freedoms (OUP 2013), 579. 
full-fledged prohibitions, the then Articles 67 to 73 on the free movement of capital were markedly less ambitious. ${ }^{2}$ Article $67(1)$, for instance, provided that:

During the transitional period and to the extent necessary to ensure the proper functioning of the common market, Member States shall progressively abolish between themselves all restrictions on the movement of capital belonging to persons resident in Member States and any discrimination based on the nationality or the place of residence of the parties or on the place where such capital is invested.

Only those restrictions necessary to ensure the proper functioning of the common market, therefore, were to be progressively abolished. Article 68 had a similar ring to it, where it held that Member States should be as liberal as possible in granting such exchange authorisations as would still be necessary after the entry into force of the Treaty. Article 71 similarly required that Member States should endeavour to avoid introducing within the Community any new exchange restrictions on the movement of capital and current payments connected with such movements or to make existing rules more restrictive.

This restrictive approach to the liberalization of capital movements can be understood from the economic situation in Europe at that time. The Court of Justice of the European Union (CJEU) also respected the more reserved language of the Treaty provisions on capital, and at this stage did not apply the same expansive and effect-driven interpretation it applied to the other freedoms. ${ }^{3}$ The limited Treaty provisions and the cautious interpretation by the CJEU left a gap in the free movement of capital, which was gradually filled with secondary legislation. It was not until 1990, however, that free movement of capital was really established as a basic principle of EU law by Council Directive $88 / 361 .^{4}$

2 For more general discussion see inter alia Cf. J. Usher, The Law of Money and Financial Services in the European Community (Oup, 1994), ch. 1 or L. Flynn, 'Free movement of capital' in Catherine Barnard and Steve Peers (eds.), European Union Law (OUP 2014), 443.

3 See, for instance, Case 203/80, Casati [1981] ECR 2595. See on the general tendency for expansive interpretations of prohibitions and restrictive interpretations of justifications $\mathrm{EU}$ Chapter 9, and for specific examples EU Chapters 10, 11 and 12.

4 Council Directive 88/361, oJ [1988] L178/5, effective as from 1 July 1990. See on this process further J. Snell, 'Free movement of capital: Evolution as a non-linear process' in P. Craig and G. De Búrca (eds), The Evolution of EU Law (OUP 2011), 547. 


\subsubsection{Directive 88/361 and the Concept of Capital}

Directive $88 / 361$ prohibited all restrictions on movements of capital taking place between persons resident in Member States. ${ }^{5}$ In line with the other freedoms, it only allowed several limited exceptions to this general prohibition. Article 4 of Directive 88/361, for instance, allowed Member States to adopt all requisite measures to prevent infringements of their laws and regulations, inter alia in the field of taxation and prudential supervision of financial institutions, or to lay down procedures for the declaration of capital movements for purposes of administrative or statistical information.

Directive 88/361 was replaced by the new Treaty provisions on capital in the Treaty of Maastricht and is no longer in force. Yet it remains relevant for the free movement of capital because the CJEU still uses the nomenclature contained in Annex I to the Directive to interpret the current Treaty provisions on capital, especially to define the concept of capital. The nomenclature classifies capital movements according to the economic nature of the assets and liabilities they concern, denominated either in national currency or in foreign exchange, and can hence also be a useful tool to interpret the EAC provisions on free movement of capital. The nomenclature covers direct investments, investments in real estate, operations in securities normally dealt in on the capital market or money market, operations in units of collective investment undertakings, operations in current and deposit accounts with financial institutions, credit cards related to commercial transactions, financial loans and credits, sureties and other guarantees or rights or pledge, transfers in performance of insurance contracts, personal capital movements, as well as the physical import and export of financial assets.

\subsubsection{From Ugly Duckling to Global Swan: The Treaty of Maastricht and Beyond}

The next major step in liberalizing the movement of capital was taken with the 1992 Treaty of Maastricht. ${ }^{6}$ With Maastricht, the free movement of capital leapfrogged from the least developed freedom to the most far reaching one. Capital became the only freedom that also applies to third countries, meaning that it not only prohibits restrictions to the movement of capital within the $\mathrm{E} U$, but also to the movement of capital to and from third countries, albeit with some extra exceptions. Later Treaties, including the 2009 Treaty of Lisbon, retained this broad scope for the free movement of capital, which now is contained in Article 63 TFEU:

5 See Council Directive 88/361 Article 1.

6 See also E U Chapter 1 for the broader importance of this Treaty for European integration, and capital and EMU in particular. 
1. Within the framework of the provisions set out in this Chapter, all restrictions on the movement of capital between Member States and between Member States and third countries shall be prohibited.

2. Within the framework of the provisions set out in this Chapter, all restrictions on payments between Member States and between Member States and third countries shall be prohibited.

Capital movements include all financial operations essentially concerned with the investment of funds. Payments, on the other hand, concern transfers of foreign exchange which form the consideration for an underlying transaction. ${ }^{78}$ As indicated above, both concepts are further fleshed out by the non-exhaustive nomenclature in Annex I of Directive 88/361. ${ }^{9}$ Sometimes, moreover, it may be difficult to determine whether a certain activity, such as providing credit, falls under services, establishment or capital, as these freedoms often overlap. In such cases, the CJEU generally looks at the 'predominant' freedom, even if the case law is not yet wholly clear and consistent, and sometimes applies multiple freedoms simultaneously.10

In contrast to the original provisions, the CJEU has held that Article 63 TFEU has vertical direct effect. ${ }^{11}$ So far, however, Article 63 TFEU does not seem to have horizontal direct effect. ${ }^{12}$

See on this difference Joined cases 286/82 and 26/83 Luisi and Carbone [1984] ECR 00377 and Case 308/86 Lambert [1988] ECR-04369.

8 Case 308/86 Criminal proceedings against R. Lambert [1988] ECR-04369.

9 For examples of categories that have given rise to doubts and litigation see Case C-318/07 Persche [2009] ECR I-00359, Case C-256/06 Jäger [2008] ECR I-123, Case C-513/03 Van Hilten-van der Heijden [2006] ECR I-01957, Case C-364/o1 Barbier [2003] ECR I-15013, and Case C-35/98 Verkooijen [2000] ECR I-4071.

10 See for example Case C-196/04 Cadbury Schweppes [2006] ECR I-7995, and Case 452/04 Fidium Finanz [2006] ECR I-9521, Case C-244/11 Commission v Greece, Case C-212/o9 Commission v Portugal [2011] ECR I-10889, Case C-326/07 Commission v Italy [2009] ECR I-02291, or Case C-251/98 Baars [2000] ECR I-02787.

Case C-212/og Commission v Portugal (n. 54) para 43; Case C-112/05 Commission v Germany (n. 33) para 18 and the cited case law; Case C-326/07 Commission v Italy (n. 54) para 35; Case C-543/08 Commission v Portugal (n. 54) para 42.

11 See for the first time accepting this vertical direct effect Joined cases C-163/94, C-165/94 and C-250/94 Sanz de Lera [1995] ECR I-04821 par. 41, and later Case C-101/05 Skatteverket [2007] ECR I-11531 para 21.

12 See for example Case C-478/98 Commission v Belgium (Eurobond) [2000] ECR I-07587, Joined cases C-282/04 and C-283/04 Commission v The Netherlands [2006] ECR I-09141, Case C-112/05 Commission v Germany [2007] ECR I-08995, and C. Barnard, The Substantive Law of the EU: The Four Freedoms (OUP 2013), 586. For a different, if not as authoritative, 


\subsubsection{Restrictions and Justifications for the Free Movement of Capital}

After the broadening of the Treaty provisions in Maastricht, the CJEU also started to apply the familiar expansive interpretation to the concept of a restriction in the context of capital. Any national measure that may affect the market access of foreign investors qualifies as a restriction under Article 63 TFEU, and is therefore in principle prohibited. This includes any measures that may deter or discourage foreign investors from investing in undertakings in a Member State. ${ }^{13}$

As with the other freedoms, however, restrictions on the free movement of capital may be justified if they serve a legitimate aim in a proportionate manner. The legitimate aims are partially laid down in the Treaty, but the CJEU also applies the rule of reason to capital, which means that Member States may suggest any reasonable public objective to try and justify restrictions that are not directly discriminatory. ${ }^{14}$

Partially because it also applies to non-EU Member States, the express Treaty derogations for capital are more extensive than those for the other freedoms. To begin with, Article 65(1)(a) TFEU allows Member States to distinguish between resident and non-resident taxpayers in relation to matters of taxation, reflecting the Member States' competence over taxation. ${ }^{15}$ Article 65(1)(a) TFEU, however, is strictly interpreted by the Court, especially as far as comparability is concerned. ${ }^{16}$ Article 65(1)(b) TFE U contains the general aims of public policy and public security that may justify restrictions, and is similar to the aims mentioned in Articles 36, 45 (3) and 52 TFEU. In addition, it provides that restrictions may be justified in order to prevent infringements of national law and regulations, in particular in the field of taxation and prudential supervision of financial institutions, and to require declarations of capital movements for purposes of administrative or statistical information. ${ }^{17}$

view see J. Rickford, 'Protectionism, Capital Freedom, and the Internal Market', in Bernitz \& Ringe (eds), Company Law and Economic Protectionism (oup 2010) p. 77.

13 See for example Case C-543/o8 Commission v Portugal ECLI:Eu:C:2010:669, par. 69, Case C-464/98, Westdeutsche Landesbank Girozentrale $v$ Stefan and Republik Österreich [2001] ECR I-173, or Case C-439/97, Sandoz [1999] ECR I-7041.

14 See on the development of the rule of reason in general also EU Chapter 9 and 10, as it was first established in the context of the free movement of goods.

15 See also Case C-35/98 Verkooijen [2000] ECR I-4071.

16 See for example Case C-315/02 Lenz [2004] ECR I-7063 or Case C-559/13 Grünewald ECLI:EU:C:2015:109.

17 See for example Case C-439/97 Sandoz [1999] ECR I-7041, Joined cases C-358/93 and C-416/93 Bordessa ECli:Eu:C:1995:54, Case C-54/99 Association Eglise de scientologie de Paris [2000] ECR I-1335. In the recent restrictions imposed in Greece to protect its 
When it comes to capital movements to and from third countries, moreover, the Treaty allows four additional types of restrictions, some to be imposed at the EU level. Firstly, Article 64 (1) TFEU allows Member States to maintain restrictions that already existed on 31 December 1993, and is known as the grandfather clause. Secondly, Article 64 (2) and (3) and Article 65 (4) TFEU allow the EU, and especially the Council, to adopt measures regarding capital movements with third countries. Thirdly, Article 65 (4) TFEU concerns Council approval of restrictive tax measures concerning third countries. Lastly, Article 66 TFEU allows the Council, on a proposal from the Commission and after consulting the European Central Bank, to take safeguard measures in exceptional circumstances where movements of capital to or from third countries cause, or threaten to cause, serious difficulties for the operation of Economic and Monetary Union.

As to the rule of reason grounds for restricting the free movement of capital, the CJEU again follows the open-ended approach developed in the context of goods, allowing Member States to put forward any public interest that may potentially justify a restriction. So far, for example, the CJEU has accepted inter alia the protection of the environment, the promotion of research and development, or the safeguarding public housing as legitimate aims. ${ }^{18}$

Again in line with the other freedoms, the real bottleneck for justifying restrictions remains the proportionality test, which requires that a national measure is both suitable and necessary to achieve its legitimate aim. Especially the necessity test, which requires that there is no less restrictive way to achieve the same legitimate aim, can be difficult to satisfy. ${ }^{19}$ For example, systems of prior authorisation will generally be disproportionate as a system of post-facto declaration will often be able to safeguard the same public interests. ${ }^{20}$ When defending a restriction, therefore, the Member State has to convince the CJEU that there really is no less restrictive measure possible that may achieve the same result, whereby the CJEU tends to be more lenient if it is obvious that

banks and financial system, see European Commission, Statement /15/5271, Brussels, 29 June 2015 .

18 Joined cases C-515/99 Reisch [2002] ECR I-2157, Case C-10/10 Commission v Austria [2011] ECR I-5389, or Case C-567/07 Sint Servatius [2009] ECR I-9021.

19 In the context of capital, moreover, the CJEU sometimes separately applies legal certainty as a third criterion. See for example Case C-54/99 Association Eglise de scientologie de Paris [2000] ECR I-1335. For an example of a measure that was found proportionate see Case C-503/99 Commission v Belgium [2002] ECR I-4809.

20 Joined cases C-358/93 and C-416/93 Bordessa ECLI:EU:C:1995:54. See also Case C-483/99 Commission $v$ France [2002] ECR I-4781, for a somewhat more flexible approach. 
a national measure is bona fides and does not (also) serve protectionist aims such as protecting national champions or particular sectors of the economy.

\subsection{Economic and Monetary Union: The Legal Framework Behind the Euro}

As indicated in EU Chapter 9, an Economic and Monetary Union forms the most far reaching form of economic integration. Member States create a single currency (the euro) and transfer all monetary policy and significant parts of economic policy to the central authority. EMU can provide significant benefits, and becomes increasingly necessary as national markets become integrated. For example, EMU removes the problem of fluctuating exchange rates that may hinder free movement, and further enables and supports free movement of capital. At the same time, EMU can cause serious damage if not done correctly. Indeed, the euro simultaneously constitutes one of the crowning achievements and one of the most existential challenges facing European integration today.

The following section first discusses the long road towards EMU, followed by an overview of the legal structure eventually adopted to support the euro. Subsequently this section looks at the structural flaws in the way EMU has been structured in the $\mathrm{EU}$, which have come into sharper focus since the euro crisis, as well as the attempts so far to remedy these flaws. ${ }^{21}$ As the euro crisis is still far from resolved at the time of writing, no final conclusions can yet be drawn, but the EAC can surely benefit from the many insights generated in the EU so far, and the cautionary tales some of these insights tell. ${ }^{22}$

21 Parts of this discussion builds on the description given in S. Van den Bogaert and A. Cuyvers, 'Of Carrots and Sticks: What Direction to take for Economic and Monetary Union?', in: B. Steunenberg, W. Voermans and S. Van den Bogaert, Fit for the Future: Insights on the EU from Leiden University (Leiden University Press, 2016), as well as A. Cuyvers, The EU as a Confederal Union of Sovereign Member Peoples, Exploring the potential of American (con)federalism and popular sovereignty for a constitutional theory of the EU, (2013, Diss. Leiden), Ch 13. In addition I gratefully acknowledge the great research assistance provided by my (former) students Carlota Marianne Wolters Corte Real de Paula Coelho and Victoria Trifonchovska.

22 Clearly this Chapter can only provide a brief introduction to this vast, complex and contested topic. For further reading see supra 21 as well as the excellent discussions in K. Tuori \& K. Tuori, The Eurozone Crisis, A Constitutional Analysis, (CUP, 2014), A. Hinarejos, The Euro Area Crisis in Constitutional Perspective (oup, 2015) and F. Snyder, 'EMU-Integration and differentiation: Metaphor for European Union", in P. Craig and G. De Búrca (eds.), The Evolution of EU Law (2nd. Ed, OUP 2011). 


\subsubsection{The Long Road to EMU}

Long before the Treaty of Maastricht in 1992, a single European currency was being considered. Already in 1969 very concrete plans were developed by the Werner Commission, which produced a detailed and well-considered roadmap towards establishing an Economic and Monetary Union by 1 January 1981. ${ }^{23}$ This plan suggested that EMU would be achieved in three successive stages, and found inter alia that EMU could only work if it was accompanied by a transfer of all monetary and significant economic competences to the $\mathrm{E}$. With the benefit of hindsight, the Werner Report already pointed to many of the risks and weaknesses that would later plague the euro, and therefore might also be of great interest to the EAC.

Although the Werner plan was actually taken over in a 1971 Council Resolution on the attainment of the EMU, this resolution was never implemented. ${ }^{24}$ This failure was partially due to the economic circumstances at the time. Economic problems in the us caused the European currencies to float, taking away one of the central assumptions underlying the proposed EMU, namely the fixed exchange rates of European currencies. Instead of a Monetary Union, another mechanism was therefore adopted, which is generally referred to as the 'Snake'. The crux of this Snake was that the difference between the exchange rates of two Member States should never exceed $2.25 \%$. Already by 1977 , however, it was apparent that the snake had failed and was unable to stop the fluctuations between Member State currencies.

Besides these economic problems, the development of a real EMU was also hindered by political resistance to the transfer of economic policy to the $\mathrm{E} U$ level. Economic policy involves decisions on national spending, budgets and revenue. In other words, it concerns intensely political questions on how much money to spend and how to spend it, and consequently touches directly on national parliaments' power of the purse, the bedrock of parliamentary power. One can understand, therefore, that Member States proved rather unwilling to transfer control over economic policy to the EU, even if pooling part of their economic competences at the EU level might be necessary for EMU or beneficial in the longer run.

Even after the failure of the Snake, therefore, establishing a real EMU did not prove politically feasible. Two parallel tracks now emerged. Firstly, the European Monetary System (EMS) was introduced to combat the problem

23 For a more detailed overview of the entire process leading up to the euro see O. Issing, The Birth of the Euro, (CUP, 2008).

$24[1971]$ oJ C28/1. 
of floating exchange rates. ${ }^{25}$ The EMs created the Exchange Rate Mechanism (ERM) and the European Currency Unit (ECU). The value of the ECU was dependant on a combination of several Member State currencies. The ERM then contained some complex provisions to try and keep Member State currencies within $2.25 \%$ of their value as against the ECU. The ESM, however, did not prove robust enough to survive the currency crises of 1992 and 1993.

Secondly, a new process was started to establish full EMU in the medium term. This plan to create a currency union regained momentum in the wake of the Single European Act of $1986 .{ }^{26}$ In 1989, a committee headed by Delors, then the very influential president of the European Commission, submitted its report on how to establish an EMU. ${ }^{27}$ It proposed that EMU should be established in three phases. The first phase comprised the completion of the internal market and membership of states in the ERM, which did not require Treaty amendments. The second phase entailed the creation of a European System of Central Banks (ESCB) which was to be entrusted with the task of coordinating national monetary policy and conducting monetary policy. The third and final phase would permanently fix the exchange rates and introduce a new single currency under the auspices of the European Central Bank (ECB), which would also be established under the third phase. With its three phases, the Delors Report bears great resemblance to the earlier Werner Report. Crucially, however, Delors concluded that an effective EMU required far less transfers of economic policy competences to the EU and far less economic convergence than previously indicated by the Werner Report.

By requiring less transfers of economic policy competences, the Delors Report reduced the political costs of EMU. The Delors Report also came at an economically and politically opportune moment. Economically, the internal market project was close to completion and the Member States were experiencing high economic growth. Politically, the Berlin Wall had just come down, which fundamentally changed the nature and dynamic of European integration. Afraid of the political and economic might of a united Germany, France wanted a single European currency to bind Germany to Europe. Germany accepted to give up its very strong Deutschmark as a price for its unification, but in return did insist that the legal framework behind the new currency would follow the German model, which included a strong and independent

$25 \quad$ Bulletin EC 12-1978.

26 See on the broader importance of the SEA for revitalizing European integration and especially the internal market also Eu Chapters 1 and 9.

27 Report on Economic and Monetary Union in the European Community (EC Commission 1988). 
central bank and a primary focus of monetary policy on price stability. At this stage already, therefore, the euro was based more on political considerations than on economic ones, as well as on the rather optimistic assumptions in the Delors Report as to the economic coordination and economic convergence required to make a supranational currency work. ${ }^{28}$

With the political support of Germany and France, and on the basis of the Delors Report, the first stage of the EMU started in July 1990. In the mean time, an intergovernmental conference was set up to determine the necessary Treaty revisions to proceed to the second and third stages of EMU as set out in the Delors Report. This conference ultimately led to the commitment to a single European currency in the 1992 Treaty of Maastricht.

\subsubsection{Maastricht and the Birth of the Euro}

The Maastricht Treaty contained a clear commitment to EMU, and provided the Treaty amendments necessary for the second and third phase of the Delors Report. 1 January 1994 was set as the starting date for the second phase. Stage three, which included the creation of the European Central Bank and the introduction of the single currency, was to start no later than 1 January 1999.

Directly after the start of the third stage on 1 January 1999, the Council adopted the conversion rates at which the European currencies were irrevocably fixed and would later be exchanged for the single currency, which was still called ECU at this point. From this moment onwards, the ECU became a real currency, and exchange rate fluctuations became a thing of the past, even though Member States formally retained their own national currency. Even though the Dutch were still paying with their guilders and the Italians with their liras, in other words, these were in reality no longer different currencies, but rather different variants of the ECU, even if most people did not realize this yet.

28 On the economics of EMU, including the problem of an optimum currency union and the debates between monetarists and economists and between German ordoliberalism and French dirigisme, see inter alia K. Tuori and K. Tuori, The Eurozone Crisis, a Constitutional Analysis (CUP, 2014), D. Daianu, C. D'Adda, G. Basevi, and R. Kumar, The Eurozone crisis and the future of Europe: the political economy of further integration and governance. (Palgrave Macmillan, 2014), H. Snaith, 'Narratives of Optimum Currency Area Theory and Eurozone Governance' 19(2) 2014 New Political Economy, 183, B. Eichengreen, 'European Monetary Integration with Benefit of Hindsight', 50 (2012) Journal of Common Market Studies, 123, J. Rodden, Hamilton's Paradox: The Promise and Peril of Fiscal Federalism (CUP, 2006), W.E. Oates, 'Toward A Second-Generation Theory of Fiscal Federalism', 12 (2005) International Tax and Public Finance, 349, and R. Mundell, 'A Theory of Optimum Currency Areas' 51 (1961) American Economic Review 657. 
The start of stage three also entailed the establishment of the European Central Bank (ЕСB) to replace the European Monetary Institute (EMI). This institute had done preparatory work during stage 2, but in phase three it was time for the independent Есв to step in and take control of the single currency. The ЕСв heads the European System of Central Banks (ЕSCB) and has the exclusive competence to determine EU monetary policy. ${ }^{29}$ Member States, therefore, have lost all competences regarding monetary policy. ${ }^{30}$ The primary objective of the ЕSCB is to maintain price stability. The ЕСB's primary instrument thereby is its control over the interest rate in the Euro zone. Without prejudice to this objective of price stability, the ЕSCB also aims to support the general economic policies in the Community, acting in accordance with the principle of an open market economy with free competition. Further ESCB tasks include conducting foreign-exchange operations, holding and managing the official foreign reserves of the Member States and promoting the smooth operation of payment systems. The exclusive right to authorise the issue of banknotes within the Community also lies with the Есв. Coins may be issued by the Member States, subject to approval by the Есв on the volume of the issue.

As of 1 January 2002, the euro was introduced in all Member States participating in the EMU and, after a short transitional period, became the only legal tender in these countries, fully replacing the former Member State currencies.

To join the euro, Member States had to fulfil several legal and economic requirements. Amongst other things, they had to establish completely independent national central banks and meet the 'convergence criteria' laid down in Article 140(1) TFEU and Protocol No. 13. These inter alia required a high degree of price stability, normal fluctuation margins (ERM II), and durable convergence of interest rates. Most famously, these criteria imposed the famous deficit limit of $3 \%$ and debt limit of $60 \%$ of GDP to ensure the sustainability of the government's financial position.

On 1 January 1999, so at the start of phase three, the Council, meeting at the level of heads of state and government, found that 11 of the then $15 \mathrm{EU}$ Member States met these criteria and were allowed to join the euro. At this stage, Greece was not yet allowed to join, whereas the Uk, Denmark and Sweden did not want to join. One and a half years later, however, in July 200o, Greece was already allowed in, joining therefore even before the euro would be physically

\footnotetext{
29 See Article 127 TFEu.

3o See EU Chapter 3 on the nature of EU exclusive competences. Please note though that the national central banks are represented in the ЕSCB, and therefore it is the independent national central banks that set EU Monetary policy, together with the Есв board.
} 
introduced on 1 January 2002. Currently, 19 out of the 28 Member States have the euro as their currency. ${ }^{31}$

For Member States, joining the euro meant going beyond coordination of national economic policies. Most importantly, Member States that participate in the euro are under a binding legal obligation to keep their deficits under $3 \%$ and their debt under $60 \%$ of GDP. This stricter coordination, however, is a far cry from the real Economic Union envisioned by Werner. Member States still set their own economic policies, albeit that they have to do so within an increasingly tight framework of EU coordination and supervision. As we will see, it is precisely this gap between an exclusive EU monetary policy and an essentially intergovernmental coordination of economic policy that turned out to be one of the key flaws in the euro.

\subsubsection{The Asymmetry Between Monetary and Economic Union: The Fault Lines of the Euro}

As indicated above, the legal framework behind the euro is fundamentally asymmetric. ${ }^{32}$ Monetary policy became an exclusive EU competence, but economic policy largely remained a Member State competence. Economic and monetary policies are therefore regulated at different levels, even though both are essential for a stable euro. The primary reason for this asymmetry is that Member States did not want to transfer control over economic policy to the $\mathrm{EU}$, as it is so central to national politics. In addition, because economic policy is so connected to national politics, it also remains the question if the $\mathrm{EU}$ could be legitimate enough to wield far reaching competences over national economic policy. ${ }^{33}$

Member States, therefore, were fully aware of this asymmetry at Maastricht, but thought it could be compensated by two control mechanisms: market discipline and public discipline.

Market discipline was to be ensured by Articles 123 to 125 TFEU. Article 123 TFEU prohibits monetary financing, meaning that the ЕСВ and national central banks are not allowed to provide financial assistance, directly or indirectly, to Member States. Member States, therefore, cannot turn on the printing presses

\footnotetext{
31 See for an overview <http://europa.eu/european-union/about-eu/money/euro_en>.

32 See also J.-V. Louis, 'The Economic and Monetary Union: Law and Institutions', 41 (2004) Common Market Law Review, 1075.

33 See on the limited capacity of the EU, due to its confederal basis, A. Cuyvers, The EU as a Confederal Union of Sovereign Member Peoples, Exploring the potential of American (con)federalism and popular sovereignty for a constitutional theory of the EU, (2013, Diss. Leiden), $\mathrm{Ch} 13$.
} 
when they need more money. Article 124 TFEU prohibits privileged access to financial institutions for the EU or Member States, again preventing them from getting easy money in this manner. Article $125 \mathrm{TFEU}$, the famous no-bailout clause, prohibits the Union and Member States from assuming liability for financial commitments of other Member States. This clause was essentially designed to signal to the markets that each Member State would remain responsible for its own debts, and would not be helped by other Member States in case of default. If a bank lends money to Greece, therefore, it should only look at the financial situation of Greece, and should not expect Germany to pay back the loan if it turns out Greece cannot do so itself. Jointly, these provisions should ensure that Member States can only get additional money from the markets, and can therefore also be disciplined by those same markets. For if a Member States spends too much, and the markets know that this Member States remains solely responsible for its own debts, the expectation was that markets would ask higher and higher interest when buying the bonds of this Member State (i.e. lending it money). The higher interest would then make money more expensive, and force the Member State to borrow and spend less, so the theory went.

Public discipline was to be ensured via Articles 121 and 126 TFEU. Article 121 TFEU contains the multilateral surveillance procedure, which essentially tries to ensure closer coordination of economic policies via soft law instruments. Article 126 TFEU provides for the now infamous excessive deficit procedure ${ }^{34}$ Under this procedure, the Commission examines if a Member State has or will have an excessive deficit. If this is the case, the Council may issue recommendations to the Member State concerned. If the excessive deficits persist, the Council may eventually impose serious sanctions, including fines of up to $0.5 \%$ of GDP. The fines, therefore, are to be imposed by the Council, i.e. by the Ministers of Finance of the Member States themselves. Consequently, this system of public enforcement ultimately depended on a form of political self-policing. It required politicians to fine their colleagues for having excessive deficits, even as they knew full well that they might have excessive deficits themselves at some point in the future. ${ }^{35}$

34 See Article 126(1) TFEU and the now infamous Stability and Growth Pact, originally comprised of three elements, being a resolution by the European Council on the Stability and Growth Pact OJ [1997] C236/1, Regulation 1466/97 [1997] OJ L209/1, and Regulation 1467/97 [1997] oJ L209/6.

35 Compare for the inherent weakness of such systems also the extremely limited use of Article $259 \mathrm{TFEU}$, which allows Member States to start infringement proceedings against each other, as discussed in EU Chapter 8. 
Despite the fundamental asymmetry at its core, the euro initially performed well. Problems arose, however, when the global financial crisis erupted after the fall of Lehman Brothers in 2008, and the euro came under increasing pressure. The main trigger for the subsequent euro crisis was the near bankruptcy of Greece. After previous fraudulent figures were re-examined, it turned out that in 2009 Greece's budget deficit reached $15.4 \%$ of GDP, more than five times the maximum allowed. Because of its financial difficulties, interest rates on Greek bonds rose sharply, threatening to cut off Greece from the capital markets completely. The critical situation in Greece, moreover, led to general insecurity and instability in the markets, also causing financial difficulties for other euro area Members, in particular Ireland, Portugal, Cyprus, and Spain. It was, therefore, feared that a Greek default would cause a domino affect, leading to further defaults in much bigger euro economies that could no longer be contained or absorbed. At the height of the crisis, a complete melt-down of the European economy and the euro itself was considered a very real possibility. ${ }^{36}$

The depth, intensity and abruptness of the euro crisis pinpointed several structural flaws in the fabric of the euro, and demonstrated that several political, economic and legal assumptions underlying EMU were incorrect. ${ }^{37}$ To begin with, the financial markets had not disciplined national budgets. Quite the contrary, for a long time, most euro zone members had paid almost the same interest on their government debt as Germany, even though they were not as stable. Between 2001 and 2009, for example, even Greece could borrow against close to the same rates as Germany, even though Greece clearly had not become as economically developed as Germany overnight. Instead of disciplining Greek spending, the markets had rather facilitated a significant increase in borrowing and spending. ${ }^{38}$

Secondly, the mechanisms for public discipline had also failed to contain the economic policy of Member States within the agreed boundaries. The first signs of this failure had already been visible when in 2003 the Council, for political reasons, decided not to sanction France and Germany for their excessive deficits. ${ }^{39}$ The overall failure of this political enforcement mechanism, however, becomes even clearer when one realizes that by now all but

36 Cf. M. Ruffert, 'The European Debt Crisis and European Law' 48 (2011) CMLRev, 1777.

37 See for an excellent overview of these assumptions K. Tuori \& K. Tuori, The Eurozone Crisis, A Constitutional Analysis (CUP, 2014), as well as the literature cited supra note 28.

38 Note that if this windfall had just been used by Greece to refinance its debt and invest in structural reforms, the euro would have had a very positive impact. Instead, this golden economic opportunity was wasted largely on consumption, leading to bubbles.

See on this issue also Case C-27/04, Commission v Council, [2004] ECR I-6649. 
two euro zone members have had excessive deficits at least once, but no fine has ever been imposed.

Thirdly, it became clear that the EMU framework did not contain any mechanisms to deal with crises, such as Member States in financial distress. The system was premised on the idea that private and public discipline would always work, and that Member States would not fail. As soon as they did, however, it turned out that certain strict rules such as the 'no-bailout clause' of Article 125 TFEU became untenable. By introducing the euro, the members of the Eurozone had become so interconnected that they could not allow any euro state to default. Even discounting any arguments based on solidarity, due to contagion and spill-over effects the costs of letting one state default would simply be too great. The euro, therefore, had created the need to help euro states in crisis, but not the means to do so.

Fourthly, the original EMU framework was preoccupied with preventing public deficits and debts. Consequently, it was not sufficiently capable of detecting and dealing with macro-economic imbalances, including imbalances in competitiveness and private debt. In addition, the assumption that the euro would automatically lead to sufficient economic convergence also proved wrong. As it turned out, macro-economic imbalances had only increased and significantly contributed to the crisis, for example in Ireland and Spain, where cheap money from several Western Member States had caused enormous bubbles. Many of the economic assumptions underlying the euro, which were inter alia relied upon to assuage worries about the fact that the $\mathrm{EU}$ does not form an optimum currency area, therefore also proved incorrect.

\subsubsection{Fixing the Euro?}

Even though it had started with a financial melt-down in the us, the euro crisis therefore demonstrated several structural flaws in EMU and the carnage these flaws could cause..$^{40}$ As abandoning Greece or the euro itself were politically and economically impossible, work was started to repair the EMU and to address, to the extent possible, the structural flaws that had been identified. This section briefly discusses the different measures adopted or proposed to address these flaws. As it can obviously not go into great detail, it focusses on the key objectives and assumptions underlying the different measures, as these will be of primary interest to the EAC. We start with a discussion of the crisis measures that were taken in the heat of the crisis, and then move on to the more structural measures adopted later on. These structural measures will 
be further subdivided into measures that focus on the EU level and measures that focus on the national level.

\subsubsection{Crisis Measures to Save the Euro}

The first crisis measures concerned direct aid to Greece, so as to avoid Greece from defaulting and potentially dragging the entire euro down with it. On 2 May 2010, the euro area Member States, together with the United Kingdom, Sweden and Denmark, established the first Greek Loan Facility (GLF) of $€ 80$ billion. ${ }^{41}$ In addition, within one week of the GLF, the euro area Member States and the IMF set up a general $€_{750}$ billion emergency fund to assist any other euro state that would run into difficulties. This emergency fund consisted of the European Financial Stabilization Mechanism (EFSM) and the European Financial Stability Facility (EFSF). ${ }^{42}$ The smaller EFSM was an EU instrument, established by Regulation 407/2010 and based on the emergency clause of Article 122(2) TFEU. The EFSF, on the other hand, formally was not an EU instrument at all, but a 'special purpose vehicle' under Luxembourg private law, based on an international agreement between participating Member States: the crisis required a certain amount of legal ingenuity and flexibility at this stage. The EFSF had an effective lending capacity of $€_{440}$ billion. ${ }^{43}$ Financial assistance could only be given on the basis of strict conditionality, entailing inter alia the adoption of austerity measures and structural economic reforms. Recourse to the EFSF, therefore, meant accepting far reaching influence by the creditors on national economic policy, and probably painful spending cuts and other austerity measures. In addition to Greece, who was the first to receive assistance from the EFSF, Ireland, Portugal, Cyprus, and Spain also received financial assistance from these emergency funds at some point, often to bail out their own banks.

41 The GLF is founded on two agreements concluded on 8 May 2010, available at: $<w w w$ .eurocrisismonitor.com/Downloads/GLF.pdf $>$. The first concerns an inter-creditor agreement among the euro area lender Member States, containing the modalities of their involvement in the loan facility. The second forms a loan facility agreement which sets out the provisions governing the pooled bilateral loans.

42 The basic arrangements concerning the European System of Financial Supervision (EFSF) are laid down in a framework agreement between the EFSF as a legal entity and the euro area Member States as its shareholders. Statement by the Eurogroup, Brussels, 2 May 2010. See also A. de Gregorio Merino, 'Legal Developments in the Economic and Monetary Union During the Debt Crisis: The Mechanisms of Financial Assistance', 49 (2012) CMLRev, 1613 .

43 European Financial Stability Facility, EFSF Framework Agreement, available at: $<w w w$ .efsf.europa.eu/about/legal-documents/index.htm> (last visited on 1 February 2016). 
In addition to these emergency funds, the Есв also played a vital role in crisis management, often throwing its full weight behind the euro. It was ECB president Mario Draghi who famously pledged that the ЕСB would 'do whatever it takes to preserve the euro' and that 'it will be enough'. Even though the ЕСВ could never directly support euro states in need, it did commit trillions of euros in buying up bonds on the secondary market and other unconventional monetary instruments, relieving pressure on euro states in distress and calming markets. ${ }^{44}$

These ad hoc bilateral loans, emergency funds and interventions by the ECB managed to prevent a complete melt-down, but it quickly became obvious that overcoming the crisis required more structural solutions as well, both at the EU and at the national level. ${ }^{45}$

\subsubsection{Structural Measures at the Eu Level}

One of the first structural steps taken at the Eu level was to set up a permanent fund to support euro states in crisis, also to signal to the markets that the EU was committed to the euro and to stop speculation against the single currency. The creation of a permanent stability mechanism first required a simplified Treaty revision to insert a new third paragraph in Article 136 TFEU, actually allowing the creation of such a permanent fund by the Member States. On 2 February 2012, even before this new Treaty provision formally entered into effect, the European Stability Mechanism (ESM) was established in an international treaty concluded by the euro Member States, and eventually given an effective lending capacity of $€_{750}$ billion. Like the EFSF, however, it only provides financial assistance on the basis of strict conditionality. In light of the, often far reaching, conditions that must be met, Member States will only ask for assistance from the ESM where they have no other options left. This is also intended to counter the moral hazard of States simply spending too much as they expect to be bailed out by the ESM anyway. ${ }^{46}$

44 For the legal tension this created between the Есв, the CJEU and the German Constitutional Court see the омт Saga, played out in BVerfGE 2 BvR 2728/13 (2014) омт (referral CJEU), Case C-62/14, Gauweiler (омт), ECLI:Eu:C:2015:40o, and BVerfGE, 2 BvR 2728/13, 2 BvR 2729/13, 2 BvR 2730/13, 2 BvR 2731/13, 2 BvE 13/13 (2016) OMT (final decision).

See also K. Armstrong, 'The New Governance of EU Fiscal Discipline', 38 (2013) European Law Review. 601, or S.C.G. Van den Bogaert and V. Borger, 'Twenty Years After Maastricht: The Coming of Age of the EMU?', in M. de Visser \& A.P. van der Mei (eds.), The Treaty on European Union 1993-2013: Reflections from Maastricht (Intersentia, 2014), 451.

46 Cf on this risk T.J. Goodspeed, 'Bailouts in a Federation,' 9 (2012) International Tax and Public Finance, 409 . 
In addition, measures were adopted to strengthen the control over Member States' budgets and to improve overall economic policy coordination. For, if the fundamental asymmetry between economic and monetary union could not be removed on the short or medium term, the idea was to make EU control over national economic policy more effective, in a sense trying to fix the system of public control introduced at Maastricht. One important initiative in this regard is the so-called 'six-pack', which consists of six legislative measures that jointly increase budgetary discipline and create a system to prevent and detect macro-economic imbalances. ${ }^{47}$ The six-pack inter alia introduced the possibility to impose sanctions for excessive deficits by reversed qualified majority voting in the Council. ${ }^{48}$ Under this new system, any sanctions that the Commission recommends for excessive deficits will be adopted unless a qualified majority in the Council votes against the imposition of fines within 10 days. ${ }^{49}$ This mechanism increases the power of the Commission, as in theory it should be hard to find a qualified majority to block sanctions. In practice, however, even under this new mechanism no sanctions have yet been imposed, despite several Member States showing excessive deficits.

The six-pack also created the possibility of imposing sanctions in the preventive arm of the Stability and Growth Pact (SGP) and in the newly created macro-economic imbalance procedure. It also strengthened the corrective arm of the SGP, allowing sanctions that range from an interest-bearing deposit of $0.2 \%$ of GDP to an irreversible fine of $0.2 \%$ of GDP. ${ }^{50}$ In light of the important role played by fraud in the Greek tragedy, Article 8 of Regulation

47 Regulation (EU) 1173/2011 of the European Parliament and of the Council of 16 November 2011 on the effective enforcement of budgetary surveillance in the euro area oJ $2011 \mathrm{~L} 306 / 1$; Regulation (EU) 1174/2011 of the European Parliament and of the Council of 16 November 2011 on enforcement measures to correct excessive macro-economic imbalances in the euro area OJ 2011 L306/8; Reg. 1175/2011; Regulation (EU) 1176/2011 of the European Parliament and of the Council of 16 November 2011 on the prevention and correction of macro-economic imbalances oJ 2011 L306/25; Reg. 1177/2011; Council Directive 2011/85/EU of 8 November 2011 on requirements for budgetary frameworks of the Member States oJ 2011 L306/41.

48 See Articles 4(2), 5(2) and 6(2) of Regulation 1173/2011. The system of reverse qualified majority voting has also been introduced in the macro-economic imbalances procedure in relation to euro area Member States. See Article 3(3) of Regulation 1174/2011.

49 R. Palmstorfer, 'The Reverse Majority Voting under the 'Six Pack': A Bad Turn for the Union?' 20 (2013) European Law Journal, 186.

50 See especially Regulation 1173/2011. For macro-economic imbalances see Regulation $1176 / 2011$. 
1173/2011 also introduced a possible fine of up to $0.2 \%$ of GDP for the manipulation of statistics.

In addition to the six-pack, a so called two-pack was also adopted in May $2013 .{ }^{51}$ These two regulations primarily aim to improve the coordination of national budgets, and inter alia help establish the 'European Semester'. Under the European Semester, euro zone members must submit their draft budgets to the Commission and the Eurogroup following a standard time-line, and take Commission and Council opinions and recommendations into account when adopting their final budgets. This mechanism ensures that the Commission and the Council already become involved in the national budget procedure at a relatively early stage. The opinions and recommendations of the Commission and Council are not formally binding, but the main idea is that increased transparency, supervision and dialogue will guide Member States towards an economic policy that is more in line with their $\mathrm{EU}$ obligations.

\subsubsection{Structural Measures at the National Level}

One interesting measure that has also been adopted so far does not focus on the EU level, but rather tries to improve economic policy and budgetary controls at the national level. In 2012, all EU Member States except the UK and the Czech Republic signed the Treaty on Stability, Coordination and Governance (TSCG), also known as the Fiscal Compact. Although the TSCG was rushed through to appease financial markets, and therefore has many limitations, the intuition behind the Treaty is valuable.

The TSCG firstly formulates the so-called 'Golden Rule', which requires all parties to create a rule of national law which demands that the budget is either balanced or in surplus. This rule, moreover, must either be incorporated in the constitution, or else in a law guaranteeing equivalent effectiveness to a constitutional rule. ${ }^{2}$ The central idea is that the only legal instrument legitimate and powerful enough to limit national spending is the national constitution, as all lower legislation can be set aside by the same government and parliament

$5^{1} \quad$ Regulation $472 / 2013$ on the strengthening of economic and budgetary surveillance of Member States in the euro area experiencing or threatened with serious difficulties with respect to their financial stability, OJ 2013 L140/1 and Regulation 473/2013 on common provisions for monitoring and assessing draft budgetary plans and ensuring the correction of excessive deficit of the Member States in the euro area, OJ $2013 \mathrm{~L}$ 140/11.

52 SCG Treaty Art. 3(1)(a) and (b). For discussion see M. Adams, F. Fabbrini, and P. Larouche (eds), The Constitutionalization of European Budgetary Constraints (Oxford, Hart 2014). SCG Treaty Art. 3(1)(e). Note that this obligation, and hence the Golden Rule, only concerns the deficit, and not the debt ratio. 
adopting the budget. In addition to the golden budget rule, the signatories of the TSCG are also obligated to create a national correction mechanism that kicks in whenever an excessive deficit nevertheless occurs. ${ }^{53}$ Lastly, and together with the two-pack, the TSCG also requires that states create independent Fiscal Councils at the national level, which must monitor national economic policy.

The TSCG is often dismissed as a mere political gesture, largely intended to calm markets and acquire the support of Germany and the Есв for the creation of the ESM. ${ }^{54}$ Indeed the TSCG has multiple flaws and has not been implemented properly in most contracting states. ${ }^{55}$ However, at the same time, it also represents a valuable political intuition that as long as the $\mathrm{EU}$ lacks the democratic legitimacy to directly control budgets, effective budget controls must be primarily established at the national level, and then perhaps supported by secondary EU controls. ${ }^{56}$ Considering the political realities in the EAC, including the sensitivities surrounding sovereignty, such a more confederal approach to budget discipline might also fit better in the EAC, or at least provide an interesting addition to more centralizing measures.

\subsubsection{EMU and the Road Ahead}

As indicated above, all the measures adopted so far have strengthened EMU in the EU, but have not yet addressed the fundamental asymmetry at the heart of EMU. Economic policy still remains a national competence, even if supervision and coordination has improved. Consequently, the debate continues as to the future of the euro and EMU in Europe. Three general schools of thought can be distinguished in this debate. On the one extreme is the school that reasons that a monetary union can only survive as part of a full political and economic

53 SCG Treaty Art. 3(1)(e).

54 Cf for example S. Peers, 'The Stability Treaty: Permanent Austerity or Gesture Politics?', 2012 EuConst, 404.

55 See for instance P. Craig, 'The Stability, Coordination and Governance Treaty: Principle, Politics and Pragmatism', (2012) European Law Review, 231, J-H. Reestman, 'The Fiscal Compact: Europe's Not Always Able to Speak German. On the Dutch Implementing Act and the Hazardous Interpretation of the Implementation Duty in Article 3(2) Fiscal Compact', (2013) 9 European Constitutional Law Review, 480, or H.T. Burret and J. Schnellenbach, 'Implementation of the fiscal compact in the Euro area Member States: Expertise on behalf of the German Council of Economic Experts', 2014 No. 08/2013e.

56 See for a further development of this confederal take on budget controls A. Cuyvers, The EU as a Confederal Union of Sovereign Member Peoples, Exploring the potential of American (con)federalism and popular sovereignty for a constitutional theory of the $E U$, (2013, Diss. Leiden), Ch 13 . 
union, but that full economic and political union is neither feasible nor desirable. Consequently, this school comes to the conclusion that the euro should be abolished, or a new currency set up between the strongest EU economies. ${ }^{57}$

The other extreme position agrees that a monetary union can only survive as part of a full political and economic union, but draws the opposite conclusion, namely that the EU should therefore take the leap of faith towards full political and economic union. ${ }^{58}$ This perspective is epitomized by the 'five presidents report' (FPR), the most recent high level proposal on the future of EMU. ${ }^{59}$ Although it does not seem to have the full political support of all five presidents, the FPR essentially suggests the 'leap of faith' solution of creating the economic and political union needed for a stable euro. To this end, the FRP proposes four interrelated unions, being 1) a 'genuine Economic Union', 2) a Financial Union, 3) a Fiscal Union, and 4) a Political Union. Although the political union proposed is not really defined in the FPR, the measures suggested go a long way towards creating a European federation, raising serious questions about feasibility and national democracy. ${ }^{60}$

The third school basically rejects the assumption that one needs full economic and political union to create a sufficiently stable euro. Consequently, this school focusses on intermediate solutions and trying to find a middle ground that can both respect the primary sovereignty and democratic process at the national level, whilst also providing sufficient coordination and safeguards at the European level. Such solutions may look to combine insights

57 See for example P. Krugman, 'Revenge of the Optimum Currency Area' 27 (2013) NBER, 441.

$5^{8}$ See S. Van den Bogaert and A. Cuyvers, 'Of Carrots and Sticks: What Direction to take for Economic and Monetary Union?', in: B. Steunenberg, W. Voermans and S. Van den Bogaert, Fit for the Future: Insights on the EU from Leiden University (Leiden University Press, 2016).

59 Jean-Claude Juncker, in close cooperation with Donald Tusk, Jeroen Dijsselbloem, Mario Draghi and Martin Schulz 'Completing Europe's Economic and Monetary Union' (Five Presidents Report), 22 June 2015, available via: $<$ http://ec.europa.eu/priorities/economicmonetary-union/docs/5-presidents-report_en.pdf.>. Also seem the accompanying analytical note: Juncker, 'Preparing for Next Steps on Better Economic Governance in the Euro Area', Informal European Council 12 February 2015. The FPR forms an important evolution compared to the previous Commission 'blueprint for a deep and genuine economic and monetary union.' Сом(2012) 777 final, and the 2012 'Van Rompuy plan', also known as the Four Presidents Report. The Van Rompuy plan was later adopted, in an even softer version, as the 'Roadmap for the completion of EMU' in the European Council conclusions on completing EMU of 14 December 2012, EUCO 205/12.

6o Cf B. Crum, 'Saving the Euro at the Cost of Democracy' 51 (2013)Journal of Common Market Studies 614 or G. Majone, Rethinking the Union of the Europe Post-Crisis (CUP, 2014). 
from the European Semester and the TSCG in an attempt to develop a hybrid, or confederal, system that can square the circle of a single European currency based on multiple national democracies and economic policies. ${ }^{61}$ If successful, such systems could preserve the unique nature and potential of regional integration without slipping back into intergovernmentalism or leaping ahead towards uncertain federation. Yet to be successful this third school must also challenge the weight of history, and those economic schools that suggest a currency can only exist in a political union.

With Brexit, the euro crisis therefore remains one of the main challenges facing European integration today. The euro forces the EU to keep evolving and improving in its search for a new form of supranational governance that can respect national identities and democracy as the cradle of political legitimacy but that can also provide an effective answer to our globalizing reality in which public authority must be exercised above the state in order to retain its relevance and influence. As the EAC joins the rest of the world in this quest, also in the context of EMU, it may already take advantage of several practical improvements developed in the EU. For example, it may, as currently envisioned, include an emergency fund like the ESM directly from the start, instead of only creating it when a crisis hits. In addition, it can create more effective tools for coordination and supervision of national economic policy at the EAC level by taking the lessons from the Stability and Growth Pact, the six-pack and the two-pack into account. These lessons can be combined with the sound intuition of the TSCG to also try and embed primary checks on economic policy at the national level, preferably via independent institutions. Equally, it would be wise to broaden review and coordination to macro-economic imbalances right from the start, as the EAC also does not form an optimal currency union.

None of these mechanisms, however, will sufficiently solve the fundamental asymmetry between national economic policies and an EAC monetary union,

61 See for a discussion of this approach A. Cuyvers, The EU as a Confederal Union of Sovereign Member Peoples, Exploring the potential of American (con)federalism and popular sovereignty for a constitutional theory of the $E U$, (2013, Diss. Leiden), $\mathrm{Ch}$ 13, and for a more general overview of these debates. K. Tuori and K. Tuori, The Eurozone Crisis, a Constitutional Analysis (OUP, 2014), G. Majone, Rethinking the Union of the Europe Post-Crisis (CUP, 2014), B. Eichengreen 'European Monetary Integration with Benefit of Hindsight', 50 Journal of Common Market Studies, 123, M. Hallerberg, 'Fiscal federalism reforms in the European Union and the Greek crisis', 12 (2011) European Union Politics, 127, W.E. Oates, 'Toward A Second-Generation Theory of Fiscal Federalism', 12 (2005) International Tax and Public Finance, 349, M. Adams, F. Fabbrini and P. Larouche (eds), The Constitutionalization of European Budgetary Constraints (Hart, 2014), A J. Menendez, 'The existential crisis of the European Union', 14 (2013) German Law Journal, 453. 
which, as in the EU, will persist as long as the EAC does not evolve into a full political union. Consequently, on this point, as on many of the other challenges facing European integration, the EAC will join the EU in the fray of regional integration, where its unique contributions and perspectives will be warmly welcomed. For, as far as regional integration is concerned, both the challenges and opportunities are more than big enough for all of us, and certainly too big for each of us individually. 